\title{
FUEL CONSUMPTION AND EFFECTIVENESS OF ELIMINATION OF ENERGY-CROP WILLOW PLANTATION1
}

\author{
Dariusz Kwaśniewski ${ }^{\mathrm{a}}$, Tadeusz Juliszewski ${ }^{\mathrm{b}}$, Józef Walczyk ${ }^{\mathrm{c}}$, Paweł Tylek ${ }^{\mathrm{c}}$, \\ Florian Adamczyk ${ }^{\mathrm{d}}$, Jan Szczepaniak ${ }^{\mathrm{d}}$ \\ ${ }^{a}$ Institute of Agricultural Engineering and Informatics, University of Agriculture in Krakow \\ ${ }^{\mathrm{b}}$ Institute of Machinery Management, Ergonomics and Production Processes, \\ University of Agriculture in Krakow \\ ${ }^{\mathrm{c}}$ Institute of Forest Utilization and Forest Technology, University of Agriculture in Krakow \\ ${ }^{\mathrm{d}}$ Industrial Institute of Agricultural Engineering in Poznan \\ *Corresponding author: e-mail: dariusz.kwasniewski@ur.krakow.pl
}

\begin{tabular}{|c|c|}
\hline ARTICLE INFO & ABSTRACT \\
\hline $\begin{array}{l}\text { Article history: } \\
\text { Received: September } 2017 \\
\text { Received in the revised form: } \\
\text { September } 2017 \\
\text { Accepted: October } 2017 \\
\end{array}$ & $\begin{array}{l}\text { The objective of the paper was to determine fuel consumption on } \\
\text { elimination of the energy willow plantation with current mechanical } \\
\text { methods with the use of the machine research model. The paper } \\
\text { covers investigations of four machine units. The lowest fuel consump- } \\
\text { tion }\left(142.6 \mathrm{l} \cdot \mathrm{ha}^{-1}\right) \text { with the use of Meri Crusher MJS-2.0) did not }\end{array}$ \\
\hline $\begin{array}{l}\text { Key words: } \\
\text { energy willow, } \\
\text { plantation elimination, } \\
\text { fuel consumption, } \\
\text { effectiveness }\end{array}$ & $\begin{array}{l}\text { ensure effectiveness of operation of this unit. Efficiency of elimination } \\
\text { of the plantation in this case is only } 36.4 \% \text {. On the other hand, the } \\
\text { highest consumption of diesel oil }\left(776.41 \cdot \mathrm{ha}^{-1}\right) \text { was reported for FAO } \\
\text { FAR model FV } 4088 \text {, and the effectiveness of elimination was not } \\
\text { satisfactory and it was } 57.0 \% \text {. The highest effectiveness of elimination } \\
\text { of the plantation was reported for the model of a new machine. Fuel } \\
\text { consumption in this case was } 535.71 \cdot \mathrm{ha}^{-1} \text { and the willow plantation } \\
\text { elimination effectiveness was the highest and it amounted to } 94.8 \% \text {. }\end{array}$ \\
\hline
\end{tabular}

\section{Introduction}

Determination of the financial profit from exploitation is a priority of the willow plantation research. While the issues related to elimination of the plantation are of small interest. Presently, analyses most often cover the costs of setting up a plantation and possible incomes therefrom. Economic analyses most often do not include labour inputs and plantation elimination costs (Ericcson et al., 2006; McKendry, 2002; Stolarski et al., 2002).

In case of a plantation of produce, elimination means restoration of primary soil properties. Elimination of a plantation of willow cultivated for energy purposes means: (1) permanent stopping of aboveground parts of rootstocks and the root system and (2) chipping of

1 The paper was written as a part of the research project no. PBS2/A8/26/2014 funded by the National Centre of Research and Development as a part of the Research Program Applied in track A 
D. Kwaśniewski, T. Juliszewski, J. Walczyk, P. Tylek, F. Adamczyk, J. Szczepaniak

aboveground parts of rootstocks and roots (Adamczyk et al., 2015; Dubas and Tomczyk, 2005; Grzybek, 2015; Kwaśniewski et al., 2016; Stolarski et al., 2008).

Relevant evaluation of the scope and distribution of roots and size of rootstocks biomass is one of the elements of developing economically and technologically efficient plantation elimination methods together with the underground part. Amount of the root systems biomass of energy willow may depend on the type of maple, soil and habitat conditions and length of the usage period (Crow and Houston, 2004).

Therefore, allocation of energy willow biomass plays a very significant role in the elimination of plantation and research results with regard to distribution of willow roots constitue precious information for constructors of machines for plantation elimination. Limitation of the regrowth possibilities of willow sprouts is basically related to destruction of the aboveground part of the rootstock and its part that is directly above it. Therefore, mechanical chipping of the entire root system on the entire surface of the field is indispensable. A vertical and horizontal scope of thick roots in the rootstock (those with the diameter above $8 \mathrm{~mm}$ ) which should be chipped during elimination of the plantation is small and is respectively approximately 0.26 and $0.29 \mathrm{~m}$ (Juliszewski et al., 2015, Tylek et al., 2017). It justifies the use of strip operating machines that operate during reclamation of a plantation along the rows of bushes.

The basic criteria of evaluation of usefulness of such machines is their performance i.e., effective elimination of a plantation and then fuel consumption.

\section{Objective, scope and methodology of research}

The objective of the paper was determination of fuel consumption on energy willow plantation elimination with current mechanical methods and with the use of the research model of the machine for rootstocks chipping constructed as a part of the research project. The paper also determines fuel consumption on soil cutting together with rootstocks by various machines within one hour of operation. The final effect of the study is a reference and comparison of fuel consumption (diesel oil) to plantation elimination effectiveness.

The paper includes investigation of four units carried out in the twelve years old energycrop willow plantation with the surface area of 3 ha set up in Kaniów (Śląskie Voivodeship, Bielsko Biała poviat). Research was carried out in May and December 2015 and June 2016. Plant stock on a part of the plantation covered by the research was approximately 20000 pcs.ha ${ }^{-1}$.

Performance was determined with the simplified timing method including working width (variants $0.4,0.7,2.0$ and $2.30 \mathrm{~m}$ ) and working width (variants $0.5,0.8 \mathrm{~km} \cdot \mathrm{h}^{-1}$ ) for the investigated machine units (Table 1). Firstly, effective performance (in effective work time) was determined, then exploitation performance (in exploitation time - including returns and stoppages). Labour inputs on plantation liquidation were expressed in working hours per one hectare (manhour $\cdot \mathrm{ha}^{-1}$ ). Fuel consumption was determined with the full container method (Kwaśniewski et al., 2016). The paper includes methodology of calculation of fuel consumption in $\left(1 \cdot \mathrm{m}^{-3}\right)$ on soil cutting together with rootstocks by various machines within one hour of operation.

The energy-crop willow plantation elimination with the use of machines operating as soil cutters included a specific volume of soil and not only its surface. Thus, it seems that 
Fuel consumption...

fuel consumption referred to the volume of the cut soil together with rootstocks of willow better expresses the energy consumption (included in diesel oil of the tractor) than referred to the surface of the eliminated plantation. Volume of the cut soil with rootstocks within one hour was calculated by multiplication of the working width of the machine $(\mathrm{m})$ by the working speed of the machine ( $\mathrm{m}^{2}$ hour $\left.{ }^{-1}\right)$ and depth of the machine operation (m). Product expresses the volume of the cut surface area of the field by the machine within 1 hour $\left(\mathrm{m}^{3} \cdot \mathrm{h}^{-1}\right)$

Fuel consumption referred to the volume of the cut soil was calculated by division of the volume of the consumed fuel $\left(1 \cdot \mathrm{h}^{-1}\right)$ by the volume of the cut soil together with rootstocks (in the time unit $\left(\mathrm{m}^{3} \cdot \mathrm{h}^{-1}\right)$.

The fact that machines were driven by tractors with various power is imperfection of the calculated fuel consumption index referred to $1 \mathrm{~m}^{3}$ of the cut soil (Table 1). Tractors differed also with weight, so the index of fuel consumption $\left(1 \cdot \mathrm{m}^{-3}\right)$ expresses not only fuel consumption for soil cutting but also such a part of fuel that was consumed for the movement of the unit, drive wheels' slip and energy losses on mechanical gears (energy transmitted from the engine to working elements of the machine). In order to remove this imperfection of the calculated index, the amount of energy supplied by the power take-off shaft to the drive of working elements of the machine was calculated. Energy transmitted by the power take-off shaft was calculated from the following relation:

$$
E_{\text {WOM }}=\frac{M_{W O M} \cdot n_{W O M}}{9550} \cdot h \quad[\mathrm{kWh}]
$$

where:

$\mathrm{M}_{\mathrm{WOM}}$ - rotational moment at the power take-off shaft (Nm) - average value

$\mathrm{n}_{\text {wom }} \quad$ - rotations of the power take-off shaft $\left(\mathrm{min}^{-1}\right)$, average value

$9550-$ conversion factor for expressing power in kilowatts, $(\mathrm{kW})$

It may be assumed that energy transmitted by the power take - off shaft was almost completely consumed on soil cutting along with rootstocks (if we forget about slight, several-percent losses on mechanical gears).

It was assumed that the energy value of diesel oil was $9.91 \mathrm{kWh} \cdot \mathrm{l}^{-1}$. (The calculations include the volumetric mass of diesel oil of $0.83 \mathrm{~g} \cdot \mathrm{cm}^{-3}$ and calorific value of oil of $\left.43 \mathrm{MJ} \cdot \mathrm{g}^{-3}\right)$. Assuming so, fuel consumption for energy transmitted by the power take-off shaft was calculated by converting amount of this energy into fuel volume (in litres) consumed for its generation (ratio of energy transmitted by the power take-off shaft in $\mathrm{kWh}$ and calorific value of diesel oil in $\mathrm{kWh} \cdot \mathrm{l}^{-1}$ ). Calculated volume of the consumed fuel referred to 1 hour of operation (driving the machine).

Performance of the investigated units was assessed by counting the number of occurring shoots in comparison to the number of shoots on the comparative plot, where shoots were gathered. Plant stock on the separate plots before elimination was comparable.

The paper was written as a part of the scientific project no. PBS2/A8/26/2014 "Development of new technology and a functional model of a machine for reclamation of fields after cultivation of energy willow". The project was carried out by a scientific and industrial consortium: 
D. Kwaśniewski, T. Juliszewski, J. Walczyk, P. Tylek, F. Adamczyk, J. Szczepaniak

1. University of Agriculture in Krakow - the project leader:

- Faculty of Forestry (Department of Forest Work Mechanization, Department of Forest Ecology and Reclamation),

- Faculty of Production Engineering and Power Energy (Institute of Machinery Management, Ergonomics and Production Processes, Institute of Agricultural Engineering and Informatics),

2. Industrial Institute of Agricultural Machines in Poznań

- Scientific Laboratory of Agricultural Machines,

- A Team for Research and Development of Machines for Obtaining Renewable Energy, of Farm and Storage Work.

3. Company PROMAR Spółka z o.o. in Poznań.

\section{Research results}

Four units were used for the research. Three first mentioned (machine FAO-FAR model FV4088, Meri Crusher MJS-2.0, Mulcher SFM-225) were used for elimination of energy willow plantation with current mechanical methods and the fourth unit is a model of a new machine constructed as a part of the research project. Exploitation parameters of units were presented in table 1 . Working width was within 0.4 to $2.3 \mathrm{~m}$. Working depth is a scope from 0.25 to 0.35 and the working width was between $500 \mathrm{~m} \cdot \mathrm{h}^{-1}$ for mulcher SFM-255 (with the highest working width) and $800 \mathrm{~m} \cdot \mathrm{h}^{-1}$ for the remaining units.

Table 1.

Machine aggregates and their exploitation parameters

\begin{tabular}{lcccccc}
\hline \multirow{2}{*}{ Item } & \multicolumn{3}{c}{ Machine aggregate } & \multicolumn{3}{c}{ Parameter } \\
\cline { 2 - 7 } & Tractor & Power & Machine & $\begin{array}{c}\text { Working } \\
\text { width }\end{array}$ & $\begin{array}{c}\text { Working } \\
\text { speed }\end{array}$ & $\begin{array}{c}\text { Working } \\
\text { depth }\end{array}$ \\
\cline { 2 - 7 } 1 & - & - & $(\mathrm{m})$ & 0.4 & 0.3 \\
\hline & $\begin{array}{c}\text { CRYSTAL } \\
\text { ORION 170 }\end{array}$ & $176 / 240$ & $\begin{array}{c}\text { FAO-FAR model } \\
\text { FV4088 }\end{array}$ & 800 & 0.25 \\
\hline 2 & $\begin{array}{c}\text { CRYSTAL } \\
\text { ORION 161 }\end{array}$ & $118 / 160$ & $\begin{array}{c}\text { Crusher } \\
\text { Meri Crusher } \\
\text { MJS-2.0 }\end{array}$ & 2.0 & 800 & 0.3 \\
\hline 4 & $\begin{array}{c}\text { CRYSTAL } \\
\text { ORION 170 }\end{array}$ & $\begin{array}{c}\text { Mulcher } \\
\text { CFM-225 }\end{array}$ & 2.3 & 500 & 0.3 \\
\hline
\end{tabular}

Analysis of fuel consumption - referred to the surface area of the eliminated plantation (ha), operation time of the unit (h), machine performance $\left(\right.$ ha $\left.\cdot h^{-1}\right)$, or the volume of the cut soil with rootstocks $\left(\mathrm{m}^{3}\right)$ is very important since fuel consumption affects the plantation liquidation costs. Fuel consumption and work inputs for the investigated machines have been shown in table 2.

The lowest exploitation performance was characteristic for the machine FAO-FAR model FV4088 and it was $0.034 \mathrm{ha} \cdot \mathrm{h}^{-1}$. Work inputs in this case were the highest $(29.6$ 
Fuel consumption...

manhour $\left.\cdot \mathrm{ha}^{-1}\right)$ and fuel consumption per hour of operation was 26.21. The highest efficiency $\left(0.123 \mathrm{ha} \cdot \mathrm{h}^{-1}\right)$ was reported for Meri Crusher MJS-2.0 - work inputs are 8.1 manhour $\cdot \mathrm{ha}^{-1}$ and fuel consumption per one hour of operation was the lowest among the investigated aggregates and it was $17.6 \mathrm{l}$.

Table 2.

Work inputs and fuel consumption for elimination of the plantation for the investigated machines

\begin{tabular}{lccccc}
\hline Specification & Unit & $\begin{array}{c}\text { FAO-FAR } \\
\text { model FV4088 }\end{array}$ & $\begin{array}{c}\text { Crusher } \\
\text { Meri Crusher } \\
\text { MJS-2.0 }\end{array}$ & $\begin{array}{c}\text { Mulcher } \\
\text { SFM-225 }\end{array}$ & $\begin{array}{c}\text { Model } \\
\text { of a new ma- } \\
\text { chine }\end{array}$ \\
\hline $\begin{array}{l}\text { Exploitation per- } \\
\text { formance }\end{array}$ & $\left(\mathrm{ha} \cdot \mathrm{h}^{-1}\right)$ & 0.034 & 0.123 & 0.087 & 0.045 \\
\hline Work expenditures & $\left(\mathrm{man}-\mathrm{hour} \cdot \mathrm{ha}^{-1}\right)$ & 29.6 & 8.1 & 11.4 & 22.3 \\
\hline Fuel consumption & $\left(1 \cdot \mathrm{h}^{-1}\right)$ & 26.2 & 17.6 & 48.3 & 24.0 \\
\hline
\end{tabular}

Table 3 shows the total volume of the cut soil and unit fuel consumption by the investigated units on cutting one cubic metre of the soil volume along with willow rootstocks on the surface area of plants which is 1 hectare. It should be emphasised here that FAO-FAR and the newly constructed machine did not cut the entire surface of the field - whole surface area was cut by the crusher and mulcher.

Table 3.

Volume of the cut soil and unit fuel consumption by various units on cutting of one cubic metre of the soil volume along with willow rootstocks

\begin{tabular}{|c|c|c|c|c|c|}
\hline \multirow{3}{*}{ Item } & \multicolumn{2}{|c|}{ Machine aggregate } & \multicolumn{3}{|c|}{ Parameter } \\
\hline & Tractor & Machine & Volum & cut soil & Unit fuel consumption \\
\hline & - & - & $\left(\mathrm{m}^{3} \cdot \mathrm{h}^{-1}\right)$ & $\left(\mathrm{m}^{3}\right)$ & $\left(1 \cdot m^{-3}\right)$ \\
\hline 1 & $\begin{array}{l}\text { CRYSTAL } \\
\text { ORION } 170\end{array}$ & $\begin{array}{c}\text { FAO-FAR model } \\
\text { FV4088 }\end{array}$ & 96.0 & 1950 & 0.27 \\
\hline 2 & $\begin{array}{l}\text { CRYSTAL } \\
\text { ORION } 161\end{array}$ & $\begin{array}{c}\text { Crusher } \\
\text { Meri Crusher MJS-2.0 }\end{array}$ & 400.0 & 2500 & 0.04 \\
\hline 3 & $\begin{array}{l}\text { CRYSTAL } \\
\text { ORION } 170\end{array}$ & $\begin{array}{l}\text { Mulcher } \\
\text { SFM-225 }\end{array}$ & 345.0 & 3000 & 0.14 \\
\hline 4 & $\begin{array}{l}\text { CRYSTAL } \\
\text { ORION } 140\end{array}$ & $\begin{array}{c}\text { Model } \\
\text { of a new machine }\end{array}$ & 196.0 & 3325 & 0.12 \\
\hline
\end{tabular}

Source: Adamczyk et al. 2016

The volume of the cut surface of the field depended on the working width of the machine and its working depth. Since the working depth of the newly constructed machine was the highest $(0.35 \mathrm{~m})$ and only five $\mathrm{cm}$ - wide strips of non-cut soil remained and the volume of the non-cut soil on the surface area of 1 hectare was the highest of all machines 
D. Kwaśniewski, T. Juliszewski, J. Walczyk, P. Tylek, F. Adamczyk, J. Szczepaniak

taking part in experiments. Adjustment of working depth of the machine for the depth of the rootstock guaranteed, however, efficient elimination of the plantation. The volume of the cut surface of the field of the newly constructed machine within one hour was considerably lower than machines working at the entire width (crusher and mulcher).

The scope of the volume of cut soil by all investigated units (table 3) was from $96 \mathrm{~m}^{3} \cdot \mathrm{h}^{-1}$ to $400 \mathrm{~m}^{3} \cdot \mathrm{h}^{-1}$, and fuel consumption on cutting was within $0.041 \cdot \mathrm{m}^{-3}$ to $0.27 \mathrm{l} \cdot \mathrm{m}^{-3}$. It is fuel consumption which covers not only soil cutting but also fuel consumption for movement of the unit on the field.

The newly constructed machine cut $196 \mathrm{~m}^{3} \cdot \mathrm{h}^{-1}$ of soil volume and it was smaller than the volume cut by the crusher and mulcher respectively by 51.0 and $43.2 \%$. However, it was higher than the volume of the cut soil by the machine FAO-FAR by $51.0 \%$.

Table 4 presents energy transmitted by the power take-off shaft to working elements of machines calculated based on experimentally obtained average values of the rotational moment and rotations of the power take-off shaft. Power (in $\mathrm{kW}$ ) multiplied by 1 hour of operation of the machine expresses energy consumption for the machine drive (in $\mathrm{kWh}$ ).

Table 4.

Energy consumption by working elements of the machine

\begin{tabular}{lccccc}
\hline Item & Machine & Torque & $\begin{array}{c}\text { Rotations of the } \\
\text { power take-off } \\
\text { shaft }\end{array}$ & $\begin{array}{c}\text { Power on the } \\
\text { power take-off } \\
\text { shaft }\end{array}$ & $\begin{array}{c}\text { Energy transmit- } \\
\text { ted by the power } \\
\text { take-off shaft }\end{array}$ \\
\hline- & - & $(\mathrm{Nm})$ & $\left(\mathrm{rot} \cdot \mathrm{min}^{-1}\right)$ & $(\mathrm{kW})$ & $(\mathrm{kWh})$ \\
\hline 1 & $\begin{array}{c}\text { FAO-FAR } \\
\text { model FV4088 }\end{array}$ & 500 & 1050 & 54.97 & 54.97 \\
\hline 2 & $\begin{array}{c}\text { Crusher } \\
\text { Meri Crusher MJS-2.0 }\end{array}$ & 400 & 1100 & 46.08 & 46.08 \\
\hline 3 & $\begin{array}{c}\text { Mulcher } \\
\text { SFM-225 }\end{array}$ & 1400 & 1000 & 146.61 & 146.61 \\
\hline 4 & $\begin{array}{c}\text { Model } \\
\text { of a new machine }\end{array}$ & 650 & 1020 & 69.43 & 69.43 \\
\hline
\end{tabular}

Amount of the consumed fuel to the volume of the cut soil along with rootstocks for the investigated aggregates was presented in table 5 . Variability of the so calculated fuel consumption $\left(1 \cdot \mathrm{m}^{-3}\right)$ was from $0.0121 \cdot \mathrm{m}^{-3}$ for mulcher SFM-255 to $0.058 \mathrm{l} \cdot \mathrm{m}^{-3}$ for FAO-FAR.

Table 5 presents also, for comparison, consumption of diesel oil in $1 \cdot$ ha $^{-1}$ and effectiveness of plantation elimination obtained for the invesitgated machine aggregates.

In case of the used machines and the constructed one, and the technological process of the willow tree plantation elimination, the quality of its operation was the most important factor (i.e. of effective elimination). The highest efficiency of plantation elimination was reported for the model of the new machine. Efficiency of elimination is $94.8 \%$. Consumption of diesel oil in this case was $535.7 \mathrm{l} \cdot \mathrm{ha}^{-1}$ and consumption for cutting soil is $0.036 \mathrm{l} \cdot \mathrm{m}$ 3 . On the other hand, the lowest effectiveness of plantation elimination was reported for Meri Crusher MJS-2.0. It was only 36.4\%. The fact that fuel consumption in this case was the lowest is without meaning, since the effect of machine operation was not satisfactory. 
Fuel consumption...

Table 5.

Fuel consumption for cutting soil with rootstocks by various machines within 1 hour of operation

\begin{tabular}{|c|c|c|c|c|c|}
\hline Item & Machine & $\begin{array}{c}\text { Fuel consumption } \\
\text { for generation of } \\
\text { energy } \\
\text { transmitted } \\
\text { by the power take-off shaft }\end{array}$ & $\begin{array}{l}\text { Fuel } \\
\text { consumption } \\
\text { for cutting soil }\end{array}$ & $\begin{array}{c}\text { Fuel } \\
\text { consumption }\end{array}$ & $\begin{array}{c}\text { Effectiveness } \\
\text { of plantation } \\
\text { elimination }\end{array}$ \\
\hline- & - & $\left(1 \cdot h^{-1}\right)$ & $\left(1 \cdot \mathrm{m}^{-3}\right)$ & $\left(\mathrm{l} \mathrm{ha}^{-1}\right)$ & (\%) \\
\hline 1 & $\begin{array}{c}\text { FAO-FAR } \\
\text { model FV4088 }\end{array}$ & 5.55 & 0.058 & 776.4 & 57.0 \\
\hline 2 & $\begin{array}{c}\text { Crusher } \\
\text { Meri Crusher } \\
\text { MJS-2.0 }\end{array}$ & 4.65 & 0.012 & 142.6 & 36.4 \\
\hline 3 & $\begin{array}{c}\text { Mulcher } \\
\text { SFM-225 } \\
\end{array}$ & 14.79 & 0.043 & 550.6 & 88.8 \\
\hline 4 & $\begin{array}{c}\text { Model } \\
\text { of a new ma- } \\
\text { chine }\end{array}$ & 7.01 & 0.036 & 535.7 & 94.8 \\
\hline
\end{tabular}

Source: based on Adamczyk et al., 2016

In the subject literature, we may find scarce information on the energy willow plantation elimination itself, fuel consumption and costs of such a treatment. Rare studies undertaken with this regard were related to the use of simple, time or energy consuming methods (Stolarski et.al., 2008; Mańkowski et al., 2014). The results of research presented in this paper introduce the issues related to fuel consumption and effectiveness of energy willow plantation elimination with the use of various machine aggregates. They may also suggest which of the methods of willow plantation elimination will be the most favourable with regard to effectiveness of elimination and what will be the fuel consumption.

\section{Conclusions}

1. Work inputs for willow plantation elimination were varied and depended on the working widths and working speeds of the investigated units. Work inputs were within 8.1 manhour $\cdot \mathrm{ha}^{-1}$ to 29.6 manhour ha ${ }^{-1}$. Diesel oil consumption per one hour of operation was 17.6 to $48.31 \cdot h^{-1}$.

2. The lowest fuel consumption for cutting soil $\left(0.0121 \cdot \mathrm{m}^{-3}\right)$ was reported for Meri Crusher MJS-2.0. If we assume fuel consumption by the newly constructed machine $=100 \%$ then fuel consumption by this machine was lower $61.7 \%$ in comparison to FAO-FAR FV 4088 and by $20.0 \%$ in comparison to mulcher SFM-225. While it was higher by $67.5 \%$ in comparison to the crusher.

3. The lowest fuel consumption with the use of the crusher $\left(142.61 \cdot \mathrm{a}^{-1}\right)$ does not ensure operation effectiveness of this unit. Effectiveness of elimination of the plantation in this case is on- 
D. Kwaśniewski, T. Juliszewski, J. Walczyk, P. Tylek, F. Adamczyk, J. Szczepaniak

ly $36.4 \%$. On the other hand, the highest consumption of diesel oil $\left(776.41 \cdot \mathrm{ha}^{-1}\right)$ was reported for FAO FAR and the effectiveness of elimination was not satisfactory and it was $57.0 \%$.

4. The highest effectiveness of elimination of the plantation was reported for the new machine constructed as a part of the research project no. PBS2/A8/26/2014. Fuel consumption in this case was $535.71 \cdot \mathrm{ha}^{-1}$ and the willow plantation elimination performance was the highest and it amounted to $94.8 \%$.

\section{References}

Adamczyk, F., Frąckowiak, P., Szczepaniak, J., Wąchalski, G. (2015). Analysis of the use of typical tillage tools for lifting and pulling willow rootstocks. In: Utilization of agricultural and forest machinery in research and teaching. Prace Komisji Nauk Rolniczych, Leśnych i Weterynaryjnych 22, PAU Kraków, 215-223.

Adamczyk, F., Frąckowiak, P., Juliszewski, T., Kwaśniewski, D., Pietrzykowski, M., Szczepaniak, J., Tylek, P., Walczyk, J., Woś, B. (2016). Likwidacja plantacji wierzby energetycznej. Wyd. Przemysłowy Instytut Maszyn Rolniczych w Poznaniu. ISBN 978-83-940788-7-4.

Crow, P., Houston, T.J. (2004). The influence of soil and coppice cycle on the rooting habit of short rotation poplar and willow coppice. Biomass and Bioenergy, 26(6), 497-505.

Dubas, J. W., Tomczyk, A. (2005). Zaktadanie, pielegnacja i ochrona plantacji wierzb energetycznych. Wydawnictwo SGGW Warszawa. ISBN 83-7244-617-2.

Ericsson, K., Rosenqvist, H., Ganko, E., Pisarek, M., Nilsson, L. (2006). An agro-economic analysis of willow cultivation In Poland. Biomass and Bioenergy, 30(5), 16-27.

Grzybek, A. (2015). Bioenergia w Polsce. Uprawy energetyczne w Polsce - Stan obecny. Seminarium pt. Uprawy energetyczne w Centralnej i Wschodniej Europie. Instytut TechnologicznoPrzyrodniczy. Warszawa, 23-24 kwietnia 2015 r.

Juliszewski, T., Kwaśniewski, D., Pietrzykowski, M., Tylek, P., Walczyk, J., Woś, B., Likus, J. (2015). Root biomass distribution in an energy willow plantation. Agricultural Engineering, 4(156), 43-49.

Kwaśniewski, D., Juliszewski, T., Walczyk, J., Tylek, P., Adamczyk, F., Szczepaniak, J. (2016) Work inputs and costs of eradication of Energy willow plantation. Agricultural Engineering, 4(160), 137-146.

Mańkowski, S., Markowski, P., Choszcz, D. (2014). Metody usuwania karp. Zieleń Miejska, 9(89), 38-41.

McKendry, P. (2002). Energy production from biomass (part 1): overview of biomass. Bioresource Technology, 83, 37-46.

Stolarski, M., Kisiel, R., Szczukowski, S., Tworkowski, J. (2002). Opłacalność produkcji wierzb krzewiastych na gruntach rolniczych w krótkich rotacjach i przy różnym zagęszczeniu roślin. Roczniki Nauk Rolniczych, T. 89, z. 2, 96-105.

Stolarski, M., Kisiel, R., Szczukowski, S., Tworkowski, J. (2008). Koszty likwidacji plantacji wierzby krzewiastej. Roczniki Nauk Rolniczych, Seria G., T.94, z.2, 172-177.

Tylek, P., Pietrzykowski, M., Walczyk, J., Juliszewski, T., Kwaśniewski, D. (2017). Root Biomass and Morphological Characterization of Energy Willow Stumps. Croatian Journal of Forest Engineering, 38, 47-54. 


\section{ZUŻYCIE PALIWA A EFEKTYWNOŚĆ LIKWIDACJI PLANTACJI WIERZBY ENERGETYCZNEJ}

Streszczenie. Celem pracy było określenie zużycia paliwa na likwidację plantacji wierzby energetycznej dotychczasowymi metodami mechanicznymi oraz $\mathrm{z}$ wykorzystaniem modelu badawczego maszyny. Zakresem pracy objęto badania dla czterech agregatów maszynowych. Najmniejsze zużycie paliwa $\left(142,61 \cdot h^{-1}\right)$ z wykorzystaniem kruszarki Meri Crusher MJS-2.0) nie zapewniało skuteczności działania tego agregatu. Efektywność likwidacji plantacji w tym przypadku to tylko 36,4\%. Z kolei największe zużycie oleju napędowego $\left(776,4 \mathrm{l} \cdot \mathrm{ha}^{-1}\right)$ odnotowano dla maszyny FAO FAR model FV 4088, a efektywność likwidacji nie była zadawalająca i wynosiła 57,0\%. Największą skuteczność likwidacji plantacji odnotowano dla modelu nowej maszyny. Zużycie paliwa wynosiło w tym przypadku 535,7 1·ha ${ }^{-1}$ a efektywność likwidacji plantacji wierzby była największa bo aż $94,8 \%$.

Słowa kluczowe: wierzba energetyczna, likwidacja plantacji, zużycie paliwa, efektywność 